\title{
Social innovation living labs and public action: an analytical framework and a methodological route based on pragmatism
}

\author{
THIAGO MAGALHÃES ${ }^{1}$ \\ CAROLINA ANDION ${ }^{1}$ \\ GRAZIeLA Dias ALPERSTEDt ${ }^{1}$
}

${ }^{1}$ Universidade do Estado de SANTA Catarina / Programa de Pós-Graduação em AdMINISTRaÇão, Florianópolis / SC - BrazIL

\begin{abstract}
This article proposes an analytical framework and a methodological route to understand the processes of collective learning, co-construction and diffusion of knowledge in social innovation ecosystems put into practice through social innovation living labs. We propose a dialogue between the debate about living labs and the pragmatist authors of the sociology of public problems and public action fields that adopt the notion of public inquiry developed by John Dewey. The study contributes to the field by proposing a new theoretical approach to study the process of democratic experimentalism in public arenas and discusses the challenges of its application, presenting the methodological path adopted in the empirical research carried out in the public arena of protection of children and adolescents' rights in Florianopolis, Brazil. The findings help to advance the understanding of social innovation living-labs and their contribution as spaces for strengthening local public action, promoting democratic learning and inventing new responses to public problems.
\end{abstract}

Keywords: Social Innovation. Social innovation living labs. Public action. Democratic experimentation.

\section{Laboratórios vivos de inovação social e ação pública: um enfoque analítico e um caminho metodológico baseados no pragmatismo}

\section{Resumo}

Este artigo propõe um enfoque analítico e um caminho metodológico para compreender os processos de aprendizagem coletiva, co-construção e difusão de conhecimento nos ecossistemas de inovação social colocados em prática, por meio de laboratórios vivos de inovação social. Para tanto, promove um diálogo entre o debate sobre os living labs e os autores pragmatistas dos campos da sociologia dos problemas públicos e da ação pública que resgatam a noção de "investigação pública" desenvolvida por John Dewey. Como contribuições, o texto propõe uma abordagem teórica para o estudo dos processos de experimentação democrática coproduzidos nas arenas públicas da cidade e discute os desafios da sua aplicação, apresentando o caminho metodológico adotado na pesquisa empírica que está sendo realizada na arena pública de garantia dos direitos da criança e do adolescente em Florianópolis, Brasil. As conclusões lançam pistas para avançar na compreensão dos laboratórios vivos de inovação social e sua contribuição, enquanto espaços de fortalecimento da ação pública local, para a aprendizagem democrática e invenção de novas respostas aos problemas públicos nas cidades.

Palavras-chave: Inovação social. Laboratórios vivos de inovação social. Ação pública. Experimentação democrática.

\section{Laboratorios vivos de innovación social y acción pública: un enfoque analítico y un camino metodológico basados en el pragmatismo}

\section{Resumen}

Este artículo propone un enfoque analítico y un camino metodológico para comprender los procesos de aprendizaje colectivo, coconstrucción y difusión del conocimiento en ecosistemas de innovación social puestos en práctica a través de laboratorios vivos de innovación social. Con este fin, proponemos un diálogo entre el debate sobre los laboratorios vivos y los autores pragmatistas de los campos de la sociología de los problemas públicos y de la acción pública que rescatan la noción de "investigación pública" desarrollada por John Dewey. Como aporte, el texto propone un nuevo acercamiento analítico para el estudio de dinámicas de experimentación democrática en arenas públicas y aborda los retos de su aplicación, presentando el camino metodológico adoptado en la investigación empírica que se está llevando a cabo en la arena pública para garantizar los derechos de los niños y adolescentes en Florianópolis, Brasil. Las conclusiones arrojan pistas para comprender los laboratorios vivos de innovación social y su aporte como espacios para fortalecer la acción pública local, promover aprendizaje democrático e inventar nuevas respuestas a los problemas públicos en las ciudades.

Palabras clave: Innovación social. Laboratorios vivos de innovación social. Acción pública. Experimentación democrática. 


\section{INTRODUCTION}

The field of study on social innovation has expanded in the last decades, encompassing areas such as administration, public administration, economics, urbanism, political science, and sociology. Research have flourished in several countries and the term 'social innovation' has gained numerous definitions, based on different understandings of the phenomenon, as discussed by Bignetti (2011), Moulaert, MacCallum and Hillier (2013), Howaldt, Domansky and Kalekta (2016), among others. According to Janin and Pecqueur (2016), this increase in studies on the subject occurs at a time of intense complexity of public problems and crisis of modern democracies, culminating in the inefficiency of models, strategies, and devices of public action previously used.

In this context, social innovation dynamics are seen as new collaborative forms of intervention to address local public problems, both in urban and rural environments (NEUMEIER, 2012; HODSON, GEELS and McMEEKIN, 2017). According to Andion, Ronconi, Moraes, et al. (2017), such innovations are not the product of a single actor, nor do they appear naturally - they emerge in 'public arenas' (CEFAï, 2002), understood as spaces for confrontation and cooperation. In these arenas, 'problematic situations' gain meaning, are shared, and mobilize different actors (besides the government), who become subjects of public action (LASCOUMES and LE GALÈS, 2007).

This article is based on a pragmatic perspective ${ }^{1}$. In this sense, social innovation is understood as consequence of situated public actions produced by the association among different actors, resources, and devices. In networks actors and "actants" (LATOUR, 2012) perform collectively and co-produce interventions to address public problems in a territory, either involving the state or not. It is a comprehension that values the influences of connections, agreements and conflicts among different actors and sectors that make up social innovation ecosystems (SIEs) (ANDION, ALPERSTEDT and GRAEFF, 2019 and 2020). This perspective considers the interactions and effects of intersectoral projects that can generate collective intelligence, as well as cross-sectional actions and engagement, co-producing new responses to urban problems (HOWALDT and KOOP, 2012; HOWALDT, KALETKA, SCHRÖDER et al., 2018; PELKA and TERSTRIEP, 2016; WOLFRAM and FRANTZESKAKI, 2016).

As these authors point out that studying the networks within SIEs implies developing systematic research to understand and support the creation of spaces for communication, cooperation, and co-construction of knowledge in these ecosystems. It is central, therefore, to investigate the emergence and role of social innovation living labs (SILLs) in the promotion of collective learning in SIEs, and the strengthening of local civic capacity (BRIGGS, 2008; LEMINEN and WESTERLUND, 2016).

Some studies discuss SILLs as spaces for the production of collective learning and intelligence in SIEs. According to Roux and Marron (2016), these laboratories respond to a need for democratization of information and knowledge, generating a better understanding of reality to face the challenges in public administration and modern democracies. Janin and Pecqueur (2016) reinforce this argument, showing that SILLs can be important instruments to rethink public action. However, they stress that not every living lab promotes social innovation, which involves the appreciation of collaborative processes in order to co-create new repertoires and solutions. Social innovation occurs through dialogue among different actors and forms of knowledge, such as scientific, practical, and common knowledge (ROUX and MARRON, 2016; LÉVESQUE, 2016).

Recent works on living labs (LLs), such as Masi (2016), Schiavo, Santos-Nogueira and Vera (2013), and Howaldt, Kaletka, Schröder et al. (2018), show that the interpretation of LLs based on a traditional perspective of innovation prevails in the literature, focusing on their economic, technical, and productive dimensions. These authors highlight the need for new

\footnotetext{
${ }^{1}$ Classical pragmatism is a philosophical stream that emerged in the early twentieth century, from the works of Charles Peirce and William James and will develop in the following decades with the works of John Dewey and George Herbert Mead, among others. Several authors describe the influence of classical pragmatism in the social sciences, which still exists today (COMETTI, 2010; FREGA, 2015). More recently, in the late 1980s, these studies will also inspire what some describe as a "pragmatic turn" and the emergence of different theoretical approaches, especially in sociology, which make a counterpoint to traditional critical sociology. As examples we can mention the situated action theory (QUÉRÉ, 1999), the actor-network theory (LATOUR, 2012) and the theory of critical capacity or justification (BOLTANSKI and THÉVENOT, 2006). Although with differences, it can be said that pragmatism and contemporary pragmatic sociology have in common the fact that they value the experience of people and groups as central to research. "Neither rationalist nor relativist, the pragmatic point of view gives a real epistemic status to the experiences and the different procedures used to link them to collective processes" (CHATEAURAYNAUD, 2017, p.1).
} 
theoretical and practical approaches that enable interpreting SILLs considering their alignment with the particularities of social innovation dynamics.

This study aims to contribute to filling this gap and seeks to foster discussion between SILLs and recent pragmatist studies in the fields of sociology of public problems and public action. The research addresses the following question: How to identify, access, and follow the processes of collective learning, co-construction, and dissemination of knowledge produced in SILLs in public arenas of the city?

This approach is based on the seminal work of John Dewey $(1927,1956)$ discussed by contemporary pragmatist authors working in the field of the sociology of public problems and exploring the notion of social inquiry (CEFAï, 2009, 2012, 2014, 2017; CHATEAURAYNAUD, 2011; CEFAÏ and TERZI 2012; QUÉRÉ and TERZI, 2015; ZASK, 2004). For Cefaï (2017, p. 189, our translation), this type of inquiry triggers "a process of inquiry - attempting to understand and establish the public problem, in which the actors are moved by a knowledge that gives them the power to act." This inquiry capacity, which is not exclusive to specialists, refers to how 'publics' (audiences) perceive the consequence of problematic situations they experience, name, identify and interpret them, build knowledge, and propose solutions. In this sense, ordinary citizens can have an "attitude of cognition" (CEFAï, 2014, p. 24, our translation) and adopt methods to address the public problems they face.

Bringing this discussion to the scope of studies on governance and public action, other authors refer to these dynamics as 'democratic experimentalism,' which help to relate the institutional dimensions of regulation and legitimacy to the dimension of problem-solving in public administration (ANSELL, 2012; BOHMAN, 2004; BRIGGS, 2008; FUNG and WRIGHT, 2003; FREGA, 2019; SHIELDS, 2008). As Frega (2019) highlights, knowing the processes of democratic experimentalism is a way of understanding how the interface between democracies and social innovation processes occurs (or not), or how the various 'publics' engage in processes to reinvent institutions.

Thus, SILLS are interpreted here as 'laboratories of public action' in which local problematic situations can be identified, interpreted, understood, and addressed, generating possibilities for democratic experimentalism. As Lascoumes and Le Galès (2007) discuss, this perspective allows facing public policies and actions as 'non-controlled' experiments in the making, interpreted when put into practice.

From this backdrop, the study tackles the research question while pursuing two interrelated objectives. The first is to build and propose a theoretical and analytical approach that brings the debate on SILLs closer to the discussion on public action, exploring the political dimension of the dynamics of social innovation - which is an aspect little addressed in the literature. The second objective is to present the practical application of the approach proposed, through an 'ethnography of public arenas' (CEFAï, 2007). The article discusses the empirical challenges of the methodological approach and exemplifies its contributions, presenting a study under development in the city of Florianópolis (Brazil), which examines the public policy on children and adolescents' rights protection.

The research focuses on the theoretical and methodological aspects of the approach, and therefore, the results will not be analyzed in depth. The article intends to advance the debate on SILLs and their relationship with the public action, inspiring new research on the subject in different contexts and territories.

\section{FROM LIVING LABS TO SOCIAL INNOVATION LIVING LABS}

The creation of a laboratory in the Massachusetts Institute of Technology (MIT) to involve residents in city planning, at the end of the 1990s, was a milestone in the debate about the living labs (LLs). The concept was then adopted in the area of technological innovation systems, understood as a user-driven methodology to detect, test, and validate their perception of technological products (YAÑEZ-FIGUEROA, RAMIREZ-MONTOYA and GARCIA-PEÑALVO, 2016). After 2006, the theme gained relevance when the European Commission (EC) launched a call for support for innovation projects based on the LLs methodology and with the emergence of the European Network of Living Labs (ENoLL). The purpose of this network was connecting LLs to stimulate sharing and dissemination of knowledge on the subject. 
Despite the different perspectives, the essence of the concept of 'living labs' lies in the original idea of the early 2000s, which was based on the involvement of users in processes of new product development. Leminen and Westerlund (2014), point out that new approaches to LLs have been developed more recently, defining them as spaces to foster innovation based on user-centric open innovation methodologies.

With the strengthening of ENoLL, studies began to explore the first experimentations of social laboratories, as citizen laboratories, urban laboratories, and, later, the social innovation living labs (SILLs). SILLs may be considered, therefore, as a form of LLs focused on urban development, using information and communication technologies (ICTS) (MULVENNA, BERGUALLKAREBORN, WALLACE et al., 2010; RAMÓN, POMPEI, LÓPEZ et al., 2016).

For Pinto and Fonseca (2013), the concept is centered mainly on experiences of social entrepreneurship, focused on technological solutions to social problems. It is possible to observe the emergence of experiences concentrated on the promotion of SILLs in the last decades, as well as several studies based on the perspective of the technological social entrepreneurship, such as Nyströn, Leminen, Westerlund et al. (2013), Herselman and Callaghan (2015), and Gascó (2017). The literature shows that, in most cases, these laboratories are created mainly by research centers, government agencies, and universities.

However, Schiavo, Santos-Nogueira, and Vera (2013) demonstrated that, in Latin America, non-governmental organizations (NGOs) and groups of citizens play a prominent role in creating and promoting SILLs, seeking responses to local needs or social problems, from the perspective of those affected. Yañez-Figueroa, Ramirez-Montoya, and Garcia-Peñalvo (2016) argue that the methodology of SILLs, therefore, searches solutions to local social problems, considering the point of view of the public experiencing these problems.

Along the same lines, Masi (2016) and Schiavo, Santos-Nogueira, and Vera (2013) argue that SILLs must be faced as more than physical spaces for collective experimentation with technologies, or as organizations that facilitate the innovation process. SILLs, for the authors, are also networks to promote social innovation related to public problems faced at the local level. As a synthesis of this debate, Box 1 presents how the literature has characterized the SILLS.

\section{Box 1}

Types of social innovation living labs (SILLs)

\begin{tabular}{|l|l|l|}
\hline \multicolumn{1}{|c|}{ TYPES } & \multicolumn{1}{|c|}{ CHARACTERISTICS } & \multicolumn{1}{c|}{ REFERENCES } \\
\hline $\begin{array}{l}\text { Social innovation } \\
\text { lab or social lab }\end{array}$ & $\begin{array}{l}\text { Technological social entrepreneurship } \\
\text { Open innovation intermediaries } \\
\text { Cooperative design, with user involvement in IT design } \\
\text { processes } \\
\text { User-driven }\end{array}$ & $\begin{array}{l}\text { Baccarne, Logghe, Schuurman } \\
\text { et al. (2016), Leminen and } \\
\text { Westerlund (2016), Schuurman } \\
\text { (2015) }\end{array}$ \\
\hline $\begin{array}{l}\text { Urban/Rural } \\
\text { living labs }\end{array}$ & $\begin{array}{l}\text { Open innovation intermediaries } \\
\text { Knowledge sharing } \\
\text { Citizen participation via ICTs } \\
\text { Use of technology to solve urban and rural problems }\end{array}$ & $\begin{array}{l}\text { Herselman and Callaghan } \\
\text { (2015), Nyströn, Leminen, } \\
\text { Westerlund et al. (2013), } \\
\text { Yañez-Figueroa, Ramirez- } \\
\text { Montoya and Garcia-Peñalvo } \\
\text { (2016) }\end{array}$ \\
\hline $\begin{array}{l}\text { Citizen labs/ } \\
\text { Laboratorios } \\
\text { ciudadanos }\end{array}$ & $\begin{array}{l}\text { Solutions to social problems } \\
\text { Cooperation networks, plurality of actors } \\
\text { Co-construction of knowledge } \\
\text { Organized as diffused spaces, networks, ecosystems, milieu } \\
\text { Collaboration among citizens, government agencies, and civil } \\
\text { society organizations (CSOs) } \\
\text { Originated in groups of citizens, CSOs, research centers }\end{array}$ & $\begin{array}{l}\text { Gascó (2017), Pinto and } \\
\text { Fonseca (2013), Masi (2016), } \\
\text { Schiavo, Santos-Nogueira and } \\
\text { Vera (2013) }\end{array}$ \\
\end{tabular}

Source: Elaborated by the authors. 
Box 1 shows that few studies consider the particularities of social innovation dynamics in understanding SILLs. This occurs because the research works usually focus on the structural aspects of the laboratories, based on a formal vision of construction and diffusion of knowledge, centered on the specialist role and in knowledge transfer.

From a pragmatist reading, this article understands SILLs as spaces of co-construction of knowledge or spaces to confront the city's public problems. Therefore, SILLs can be stages to conduct social inquiries, in the sense established by Dewey (1927). The next section discusses this assumption exploring how pragmatist reading can help to understand and reinforce the SILLs experience and their effects on territories, allowing to analyze them as vectors of 'democratic experimentalism.'

\section{A NEW INTERPRETATION OF SILLS BASED ON PRAGMATISM}

The study of social problems and how they are faced in modern democracies is not new in the social sciences. The first studies on social problems started in the nineteenth century, in Europe, examining the vulnerability of populations living in the recently formed urban centers, after the Industrial Revolution. In the 1920s and 1930s, the field gained greater scientific weight with the emergence of the Chicago School in the United States and later, in 1951, with the creation of the Society for the Study of Social Problems (SSSP) and the Journal Social Problems, both strongly influenced by authors from the Chicago School.

The field of sociology of public problems has developed based on this tradition, gaining strength more recently with the studies of contemporary pragmatist authors (CEFAÏ, 2017; CEFAII and TERZI, 2012). These authors go beyond a merely constructivist view of social problems. They consider that public problems are constituted from experience and through a long history of confronting 'problematic situations,' permeated by a conceptual, discursive, and cognitive elaboration. According to Quéré and Terzi (2015), the public problem is thus the solidification of different situations overcome throughout history, giving rise to a process of collective learning that modifies the perception, meaning, and action around the problem over time. The identification, interpretation, inquiry and action on public problems shape, thus, both, the reconfigured problem and the publics that mobilize around it.

The source of inspiration comes from the work of John Dewey (1859-1952), an American pragmatist philosopher and pedagogist. For Dewey, knowledge is the practical solution to situations experienced in nature. This solution is obtained through systematic examination, with the specific objectives of discovering and understanding the properties of natural objects (DEWEY, 1956). Thus, knowledge about the problems comes with experience, from a process of inquiry with other actors around these same problems. Throughout his career, John Dewey created laboratory schools to implement his learning method based on experimentation, which supported the construction of several contemporary educational theories.

Dewey called this process 'social inquiry,' through which the collectives that make up a democracy co-produce knowledge from the experience of reality in their daily lives. Social or "public inquiry" (as we call here) is at the heart of his theory of democracy (DEWEY, 1927). This notion has been explored by a series of authors who discuss the processes of "democratic experimentalism" in studies on governance and public action (ANSELL, 2011, 2012; BOHMAN, 2004; FUNG and WRIGHT, 2003). For Ansell (2011), this experimentation in solving public problems is characterized by benchmarking, reciprocal information sharing, and monitoring to reduce error and expand learning. Pragmatism, according to the author, strengthens the importance of evolutionary learning that is based on (1) the emphasis on the consequences or effects of public problems; (2) reflectivity and critical thinking; and (3) deliberation and construction of "communities of inquiry."

For Cefaï (2017), this process is crucial to understand the influence of civil society on public policies and actions, going from a private perspective to building a perspective of public interest and engagement. When problematization and publicization of the situations are widespread, they can be understood as 'political processes.' For the author, public inquiry can produce "effects that impact in terms of moral - on uses, beliefs, and customs" (CEFAï, 2017, p. 189, our translation), influencing public 
authorities and the public as a whole, leading to changes in practices, structures, and institutions. Thus, it is important to identify the problematic situations or the moments when the 'natural' attitude is questioned, and the actors have to justify their arguments and actions. According to Boltanski and Thévenot (2006), these moments require new adjustments, new forms of coordination, or new agreements, representing turning points to be considered in the analysis.

Cefaï $(2002,2017)$ shows that these experiences form the public arenas, which are organized as "territories of indignation" and "laboratories of experimentation" that arise around the "problematic situations". They are characterized as collective "fields of experience" concentrated in limited or dispersed territories. These collectives are formed and regulated around common expectations and experiences. So, public arenas are understood as spaces of confrontation and cooperation in which public problems are understood and shared and where various actors, beyond the government, work together around these same problems. Box 2 explores some key concepts that have guided the construction of the theoretical-analytical approach adopted in this work.

\section{Box 2}

Key pragmatist-inspired concepts to analyze public arenas and public action

\begin{tabular}{|c|c|}
\hline KEY CONCEPTS & DEFINITION \\
\hline Public arena & $\begin{array}{l}\text { Public arena is more than the combination of institutional, technical, or legal mechanisms of } \\
\text { public action. It is more than spaces of structured positions in a political field. Public arena is a } \\
\text { place of combat, disputes but also agreements, achievements and performances with effects } \\
\text { in public action. }\end{array}$ \\
\hline $\begin{array}{l}\text { Problematic } \\
\text { situation or test } \\
\text { situation }\end{array}$ & $\begin{array}{l}\text { A situation emerging from a trouble or a perceived undesirable consequence, leading to } \\
\text { questions, examination, debate, and inquiry. }\end{array}$ \\
\hline Public & $\begin{array}{l}\text { A group of people, organizations and institutions indirectly affected by the shared perception } \\
\text { of the problematic situation's or undesirable consequences. The public may mobilize to } \\
\text { respond to the problematic situation. }\end{array}$ \\
\hline Public problem & $\begin{array}{l}\text { Different from a social problem, the public problem transcends the private domain and can } \\
\text { be perceived by different publics affected directly or indirectly by its consequences. These } \\
\text { publics may act to control such consequences. }\end{array}$ \\
\hline Publicization & $\begin{array}{l}\text { The consequences of a problematic situation do not only concern individuals who suffer } \\
\text { it directly. They create publics that seek to act on the problem and search for new } \\
\text { arrangements and coalitions to address it. }\end{array}$ \\
\hline Social inquiry & $\begin{array}{l}\text { Faced with a problematic situation, people may become stressed and question themselves, } \\
\text { they may research, experiment, discuss, try to define the problem, determine its causes } \\
\text { and effects, and establish the responsibilities. People can work in association and organize } \\
\text { themselves, testify, evaluate, argue, criticize, deliberate, question the public opinion and } \\
\text { authorities. This collective dynamic brings out, both, a problem, and its public. }\end{array}$ \\
\hline $\begin{array}{l}\text { Democratic State } \\
\text { and public action }\end{array}$ & $\begin{array}{l}\text { There is a diversity of political forms, and the archetype of a 'unified state' or 'the good state' } \\
\text { is a myth. The formation of the State is an experimental process that must be associated with } \\
\text { processes of public inquiry by engaging the public in addressing its own problems. This is how } \\
\text { the democratic State is formed and transformed. }\end{array}$ \\
\hline $\begin{array}{l}\text { Democratic } \\
\text { experimentalism }\end{array}$ & $\begin{array}{l}\text { The democratic experimentalism is a problem-solving process that combines inquiry } \\
\text { (questioning, knowledge building, and testing) with inclusive and collaborative approaches. It } \\
\text { shows the society's capacity to generalize the attitude of working to solve public problems in } \\
\text { the face of external crises, as well as its capacity to generate collective intelligence. }\end{array}$ \\
\hline
\end{tabular}

Source: Elaborated by the authors based on Dewey (1927), Cefaï (2012, 2014, 2017), and Frega (2019). 
This section may contribute to comprehend the SILLs from a different point of view. The SILLs may be considered a locus of problematization, publicization, and debate, as well as a space of co-construction of solutions to public problems. The SILLS are "living laboratories" of co-production of 'the social,' in its most precise interpretation. In the different arenas of the city, common actors can perform social inquiry processes and thus participate more actively in defining their life conditions and transforming their realities (ZASK, 2004).

\section{SOCIAL INNOVATION LIVING LAB IN THE PUBLIC ARENA OF CHILDREN AND ADOLESCENTS' RIGHTS PROTECTION IN FLORIANÓPOLIS (BRAZIL)}

This section discusses how to access and comprehend the dynamics of the public arenas based on the notion of social innovation living laboratory (SILL). The theoretical debate presented in the previous section supports the methodological path and the research strategies adopted in the empirical application of the approach proposed in this study, which brings the debate on SILLs closer to the discussion on public action and examines the political dimension of the social innovation dynamics. This section has two parts. The first one contextualizes the study, which is part of a broader research conducted in the scope of the Social Innovation Observatory of Florianopolis (OBISF). The intention is to present the public arena where the study is developed, clarifying the general lines of the broader research. The second part presents a detailed discussion of how the 'ethnography of the public arena' was carried out in the field studied - the children and adolescents' rights protection in the city of Florianópolis, Brazil -, in order to understand the processes of collective learning, and co-construction and dissemination of knowledge in this arena.

\section{Contextualizing the study}

The study presented in this article is part of a research started in 2016. This broader research involved the creation of the Observatory of Social Innovation of Florianopolis (OBISF) that carries out cartography and provides data to analyze the configuration of the social innovation ecosystem (SIE) in the city. The OBISF maps support organizations and social innovation initiatives. It offers visibility to collective groups and organizations that form the local SIE, identifying the public arenas, the actors' networks, and the public problems they address.

The observatory offers an online and open platform, launched in September 2017 (www.observafloripa.com.br), where the organizations and initiatives gain visibility and may establish connections. The platform promotes interaction and provides collaborative learning opportunities through the network of initiatives registered, who form the local SIE. OBISF was created and implemented based on an analytical framework (Figure 1), developed by Andion, Alperstedt, and Graeff $(2019,2020)$ and presented below.

The development of the framework involved a first moment of 'macro' analysis, observing the origins of the SIE and its institutional and territorial embeddedness. The research examined the public policies and institutional mechanisms supporting social innovation in the territory, as well as the main public problems of the city. After, the initiatives and the public problems were analyzed together to identify and assess the trajectory and institutional dimension of the city's SIE and demands, offering subsidies for the research design.

The second moment in the development of the framework is related to the 'meso' analysis and the network's cartography, which is carried out continuously, through the online platform. At this stage, social innovation initiatives and support organizations (those providing training, funding, and coordination, for example) are mapped and georeferenced. The initiatives are then observed, responding to a questionnaire, and receiving researchers for visits. These procedures allow collecting detailed information on their performance, incidence, and interactions. Thus, the cartography allows us to see, as the research progresses, the different networks of actors addressing the city's public problems. In May 2020, the OBISF had registered 366 social innovation initiatives and observed 136 of them. Also, the observatory registered 290 support organizations. These actors mobilize and connect around one or more public problems in the city. They form networks that make up seventeen public arenas mapped. ${ }_{2}$ These arenas involve urgent public problems, such as the Covid-19 pandemic, to broader issues, such as the city's socio-environmental problems.

\footnotetext{
${ }^{2}$ To find out more about the different public arenas mapped in Florianópolis, see <http://www.observafloripa.com.br/is-page//publicProblems>. Accessed on: Aug. 31, 2020.
} 
Figure 1

Analytical framework of the Observatory of Social Innovation of Florianopolis (OBISF)

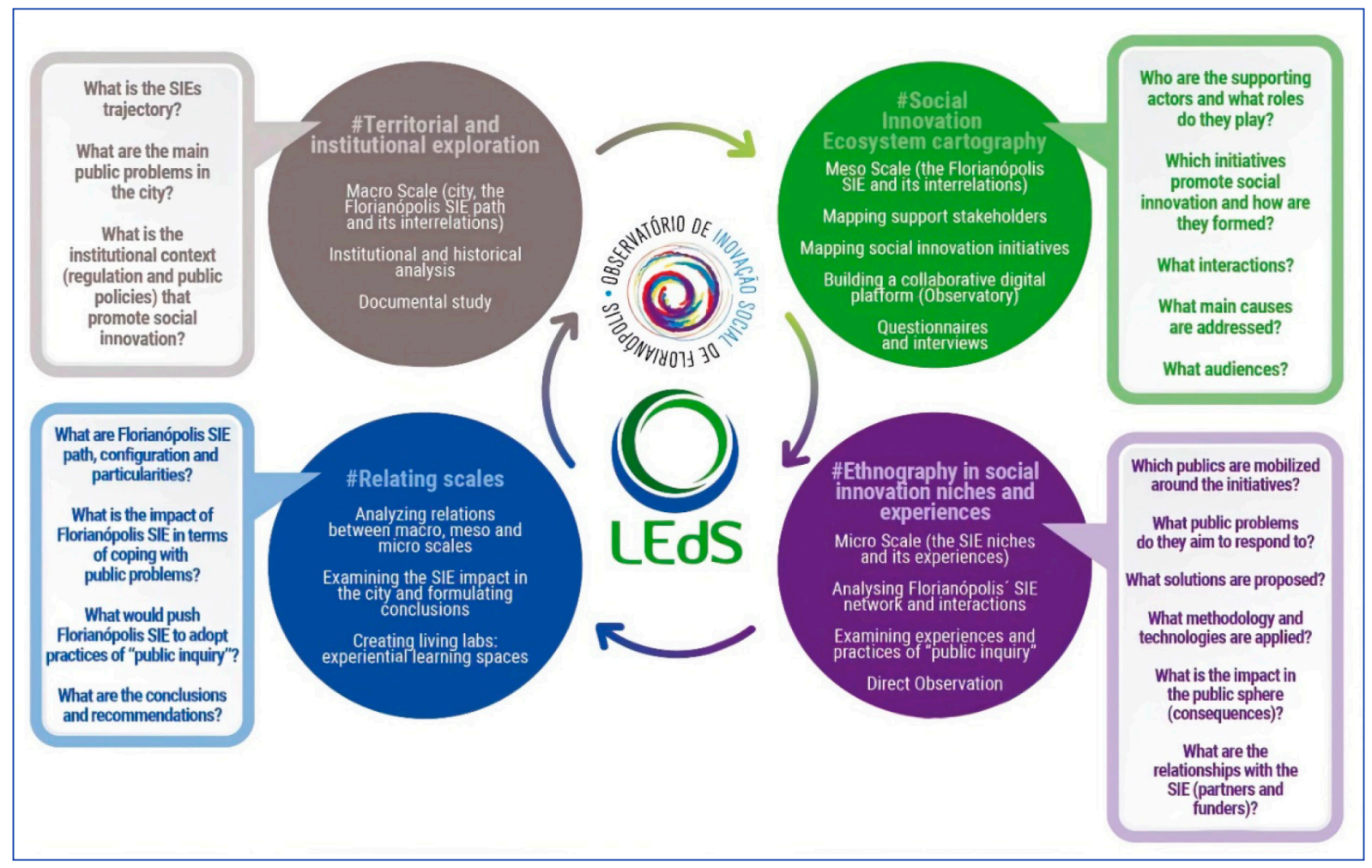

Source: Andion, Alperstedt and Graeff $(2019,2020)$.

Finally, the third moment consists of a 'micro' analysis, and the experiences of social innovation in the city are monitored through processes of "ethnography of public arenas" (CEFAÏ, 2009). The study portrayed in this article is related to this moment of the research. This type of 'applied and engaged' ethnography entails systematic researcher involvement, monitoring the dynamics of the publics that perform these public arenas. This practice is not limited to structural or institutional reading. It adopts a pragmatist perspective, connecting micro, meso and macro dimensions in a "game of scales" (REVEL, 1996), considering the longitudinal reading to understand deeply how the SIE works in the different public arenas in the territory. Therefore, it is crucial to focalize the experiences of problematization, publicization, inquiry, and collective action toward public issues emerging in these arenas.

The study presented in this article examines the public arena of children and adolescents' rights protection in Florianópolis, Brazil. We selected this arena based on its weight in the cartography conducted in the scope of the OBISF. Of the 366 initiatives mapped, until May 2020, 129 address the public problem of vulnerability of children and adolescents. In addition, researchers from the Center of Social Innovation in the Public Sphere (NISP) of the Santa Catarina State University, where this study is developed, have promoted activities of teaching, research and university extension in this arena for more than 10 years long (before the creation of the OBISF), which resulted in different publications (DAVI, 2014; GONSALVES, 2015; ANDION, MORAES e GONSALVES, 2017; GONSALVES and ANDION, 2019).

These previous research works in the public arena of children and adolescents' rights protection in the territory show that, despite having the third-highest human development index (HDI) in the country, Florianopolis has many challenges and social injustices to overcome. Two of these studies are the Vital Signs report focused on children and adolescents (ICOM, 2010, 2016), and the RAPI (annual report of indicators) (RMC, 2019). The reports mention that one in five children in the city lived in a condition of socio-economic vulnerability in 2016, with their rights at risk, situation that has gotten worse today due to the effects of the COVID-19 pandemic. These boys and girls live mostly in the more than 67 underprivileged areas in the territory, in homes located in precarious settlements with no urban facilities or land documentation. 
On the other hand, the cartography revealed the existence of a dense network of support organizations and social innovation initiatives working on this issue, serving the children and adolescents and their families. It is a network addressing problems such as domestic and sexual violence, child labor, and drug dealing (Figure 2 retrieved from the OBISF's platform illustrates the network ${ }^{3}$ ). As the initiatives registered on the platform and provided information on their work and relations, it was possible to observe their connections and the existence of multiple spaces for coordination and debate. In addition, the cartography revealed local mechanisms, methodologies, and technologies that have been created in recent years. When mapping the contours of this public arena, it is possible to observe a broad mobilization around problematic situations involving the rights of children and adolescents. Therefore, the study sought to examine "if" and "how" dynamics of 'social inquiry' and 'democratic experimentation' occurred in this arena. In the next part of this article, we discuss the methodological path adopted to identify, access, and follow the processes of collective learning, co-construction, and dissemination of knowledge in this public arena, i.e., the method used to examine the arena as a social innovation living laboratory.

\section{Ethnography of the public arena of children and adolescents' rights in the city}

According to Cefaï (2012), public arenas are formed in multiple places and moments, with a great dispersion of scenes, fields of maneuver, and exchanges of arguments among the different publics mobilized. In this sense, the research considers the interfaces of scales (REVEL, 1996) and the different scenarios where the network unfolds in order to identify the processes of collective learning in this public arena. In this context, we present and discuss the methodological path used to put into practice the ethnography of the public arena studied. As Cefaï (2009) affirms this is a "political ethnography" or an "anthropology of citizenship," and it seeks to shed light on the daily practices of the different publics involved in the public problems.

Then the next section describes the - moments of a vast fieldwork started in 2017 and ended in 2019. We discuss the techniques adopted and illustrate the contributions of each of the research stages.

\section{Mapping and analysis of the public arena's network (cartography)}

The mapping of the public arena was conducted within the scope of the OBISF. The information was collected collect through a structured questionnaire applied to representative members of social innovation initiatives and support organizations working on the issue of children and adolescents' rights protection in the territory. The majority of this collectives and organizations were observed by visits made by researchers.

The preliminary mapping (Figure 2) shows that the public arena of children and adolescents' rights protection is very prominent in the city's SIE. Of the 366 social innovation initiatives mapped out in the Observatory, until May 2019, 129 (35\%) act to promote children and adolescents' rights or combat the rights' violation. In the scope of the OBISF, two of these 129 initiatives were monitored (in green), 73 were observed (yellow) by fieldwork, and 54 were only mapped (red). In addition, 17 initiatives ended their activities during the period, i.e., they are inactive (grey). ${ }^{4}$ Finally, the figure shows the mapping of 138 support organizations that offer varied types of support to social innovation initiatives, as detailed in the description of the network elements in the figure below.

The network indicates the relationships and the diversity of actors involved. Regarding the social innovation initiatives, $109(84 \%)$ are promoted by associations, foundations, collectives, and social movements, while 11 are government-led initiatives. Two of them are initiatives started by businesses. The mapping corroborates, therefore, the weight of civil society organizations (CSOs) in this public arena.

The social innovation initiatives are related to the provision of public services, mainly through partnerships between CSOs and the local government within the framework of the public policy toward the protection of children and adolescents. As a result, the responses offered to public problems involve constant and continuing activities. Based on data from both government and

\footnotetext{
${ }^{3}$ The representation of the network in the OBISF's online portal is automatically generated by the platform's system. The coding is based on the graph theory and the resulting images express the relationships (edges) among the actors (social innovation initiatives, support organizations). The actors provide the inputs to build this representation through a questionnaire applied when they register to be part of the platform.

${ }^{4}$ The social innovation initiatives monitored are in constant analysis, followed by the OBISF's team. The observed initiatives are those that the OBISF's team visited to complement and validate the information provided in the questionnaire applied when the initiative registers on the platform. Finally, mapped initiatives are those that registered autonomously on the platform and have not yet been visited, and the initiatives that have terminated their activities are considered as 'inactive.'
} 
-CSOs, the main services offered are foster care for children separated from their biological families (11 initiatives), activities to strengthen bonds with family and community (35), after school activities (9), health issues (17), professionalization and professional integration (10), early childhood education and schooling (9), cultural activities (3), and digital inclusion (1).

Figure 2

Representation of the network in the public arena of children and adolescents' rights protection in the city of Florianópolis

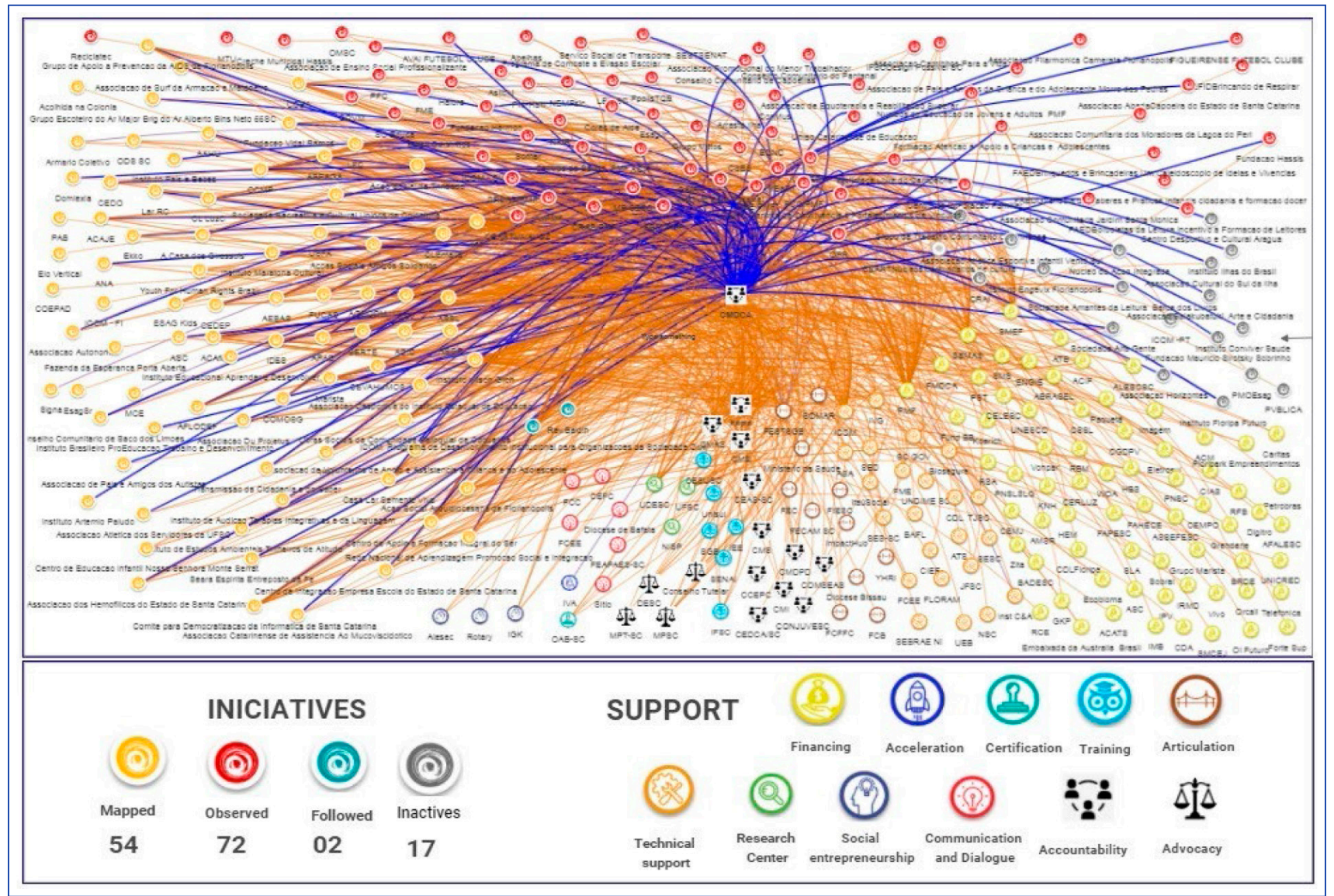

Source: Elaborated by authors from OBISF data (2020).

Regarding the support organizations, 69 of them are grant-makers - highlighting the participation of local government agencies such as the secretaries of education, health, and social assistance, and the city's fund to support initiatives protecting the rights of children and Adolescents (FloriCriança). Other activities are technical support (23), facilitating connections (11), accountability, (11), training (6), communication (6), advocacy (4), research centers (3), social entrepreneurship (3), acceleration of initiatives (1), and certification (1).

The political incidence of the social innovation initiatives in the public arena is evident, in most of the cases. They influence in the arenas they operate, both by engaging in the formal mechanisms within the public policy (involvement in participatory councils, or contracting with the local authority to deliver services) and by acting in other spaces for coordination and mobilization, such as the Florianópolis Public Policy Forum (FPPF). Among these mechanisms, the city's Participatory Council for the Rights of Children and Adolescents (CMDCA) stands out, which appears at the center of Figure 2.

Therefore, far from adopting a culture of excessive benefits and handouts, these initiatives have been protagonists in the construction of methodologies, mechanisms, and processes to improve public policies toward protecting and promoting the rights of children and adolescents. These initiatives have played a role in political pressure and mobilization by pointing out problems, as well as debating in the public arena and challenging local authorities. 


\section{Reconstitution of the trajectory and main events in the public arena (diachronic analysis)}

At this point in the study, we conducted a longitudinal analysis of the main events and instruments around the problem, the publics, their actions and consequences over time. This procedure allowed us to go beyond a structural description of the arena, contributing to obtain a better understanding of how collective learning and the ongoing processes of social inquiry arises and occurs in time. One of the main strategies adopted was to reconstitute, together with the actors, the trajectory of the public arena. The strategy was also an attempt to form a dossier on the public problem, characterized by the corpus of documents and information the actors produced over time (CHATEAURAYNAUD, 2011). This corpus was created from a documental survey, considering the last thirteen years of implementation of public policy in the municipality (2007 to 2019).

First, we conducted a study to capture "public opinion," analyzing 179 news articles retrieved from the local newspapers. The analysis sought to identify controversies (LATOUR, 2012) on the theme of protection of children and adolescents' rights. Another data collection technique consisted of monitoring the governmental agenda (in a cross-cutting perspective), of both the local legislature and executive branch. We analyzed the minutes of meetings of the FPPF, the CMDCA, the city's participatory councils of social assistance (CMAS), health (CMS), and education (CME). Other relevant documents collected for analysis were the ten-year plan for the human rights of children and adolescents of the municipality (2018-2028) and the reports of the municipal conferences about children and adolescents' rights. The study analyzed, in total, 573 documents.

After this preliminary research, 26 in-depth interviews were subsequently conducted with public servants managing and implementing the city's public policies in the area of children and adolescents including: CSOs' managers; members of the CMDCA (including former presidents of the council); public officials responsible for the protection measures toward children and adolescents at social risk; city councilors; and judges and prosecutors of children and youth courts in the city. In addition, four workshops were held (in different moments of the research) in the form of a focus group, gathering key players to discuss and validate the design of the history drafted after the documental analysis.

This diachronic analysis was important to reveal the "ballistics of public problems" (CHATEAURAYNAUD, 2011) in the arena, and how the different publics interpreted these problems (identifying the problems discussed, the information exchanged about the problems, how people spoke about them, who was held responsible, etc.). This analysis provided a closer view of how people and institutions discussed and publicized the problem in the arena (the vocabulary adopted, the main controversies, and arguments). In addition, it was possible to observe the "gradient of criticism" (CHATEAURAYNAUD and DEBAZ, 2017) and the actions the publics produced, considering that these 'publics' change throughout the process and, therefore, the arena also changes, over time.

It was possible to highlight important moments of recursiveness and setbacks, as well as moments of bifurcation, such as the mobilization and co-creation of diagnoses of the situation of children and adolescents in the territory and the Decennial Plan for the Rights of Children and Adolescents of the municipality (processes occurred from 2016 to 2018). However, it was necessary to use yet another strategy to better understand these experiences of confronting public issues, as well as exploring how they occur. Therefore, we also followed the situations experienced, as reported in the next section.

\section{Identifying and monitoring scenes of reciprocal adjustment (experiences of commitment/conflict)}

The next step after reconstituting the trajectory of the public arena, was to know the dynamics of the spaces mediating the collective experience, in situ. This analysis was essential to understand how the issues related to the protection (or violation) of children and adolescents' rights were problematized and publicized in daily situations (CEFAï, 2017). These aspects are important to access the dynamics of the social inquiry, as discussed above because the public problem effectively exists when lived as a process of collective experience. By expanding the issue to other actors beyond those directly involved, the dynamics of problematization and publicization gain the characteristics of a political process. From the establishment of the public problem, the collective action around it, its problematization, and publicization, a "field of experience" emerges (CEFAï, 2014), constituted based on the problematic situation.

We followed the forums and spaces of coordination in order to observe the actors and their arguments as a way to facilitate the analysis of the experiences in this arena and to access the situations of coordination/commitment and conflict between the different actors performing in the arena. This activity was developed through direct observation, registering the inputs in a field diary. We followed the discussions in the different spaces of coordination and dialogue identified in the cartography. First, we observed the meetings of the CMDCA and the FPPF, from 2017 to the end of 2019. In addition, through a project of university extension - connected to the broader research in which this study is inserted - and in partnership with a community institute and the CMDCA, five moments of open dialogue were held in 2018. Different actors attended these dialogues, from public 
officials from the legislative, executive, and judiciary branches to researchers, nonprofit managers, students, and members of participatory councils, including groups of children and adolescents.

This step of the study was crucial to identify and know the different publics acting in the public arena and to monitor their actions and speeches in the different scenes of reciprocal adjustment. Thus, it was possible to identify arguments, structures and mechanisms of coordination, and ongoing processes of social inquiry in a more precise manner. In addition, we had access to the debates and their developments in the performance of CSOs and the local government for the protection and promotion of rights. Therefore, was possible to access how these debates influenced the work of members of the CMDCA regarding social accountability and the activity of the members of the different areas in the judiciary and officials responsible for the direct implementation of protective measures regarding the defense of children and adolescents. Finally, the approach allows monitoring the FloriCriança fund in financing the implementation of the public policies. This methodological strategy allowed observing how the actors coordinate with each other, their scope and limits, and the consequences and learning generated. At this stage, however, we could not access much of the reality of the people affected, i.e., the children, adolescents, and their families, what was possible in the next step explored below.

\section{Follow-up with affected people and their life experience (inter- and intra-organizational analysis)}

The scales of analysis discussed above tended to privilege the official debates involving spokespersons representing the publics. However, they do not go far enough into the experiences of the affected publics, which is something crucial to a pragmatist study. Therefore, the study sought to cover this scale of reality by entering in the inter and intra-organizational field of advocacy, approaching the people affected - children, adolescents, and their families - and their experiences.

The strategy adopted counted on the coordination between research and university extension, through a project in partnership with the CMDCA and a local CSO. The project LAFI (laboratory for institutional development) was implemented in 2018 and aimed to promote dialogue and collective learning among the actors in the public arena and between these actors and the researchers.

The project was conducted in five meetings, named "Extended Dialogues" structured according to topics the participants raised. During the sessions, the participants were encouraged to engage, reflect, dialogue, and act on certain key issues related to the public policy for the protection of rights of children and adolescents. Two of these dialogues were held in the format of a public hearing in the City Council, with the participation of groups of adolescents and public managers working in the children and adolescents' rights protection system of the city. In addition to these dialogues, four workshops were held in which $40 \mathrm{CSOs}$ - that participate in the construction and implementation of the public policy (10 in each round and per city region) - co-created projects to improve their institutional development. This activity offered the CSOs the opportunity to strengthen their influence in this public arena and to advance in their work.

Through the project, it was possible to follow more closely the relationships, mobilization, and connections within the public arena. We could observe various activities, actions, and interactions that children, adolescents, families, and professionals experience when dealing with the public problem. In addition to the managers and members of the CSOs, street-level public managers - directly delivering services - were interviewed. This strategy allowed us to obtain an idea of how they act, their challenges and the consequences of their work.

The field research conducted from 2018 to 2019 offered the opportunity to find out and follow the work of CSOs in the communities. The researchers visited the organizations, observed and interviewed the beneficiaries - children, adolescents, and their families. Thus, we sought to obtain temporal sequences at the time they were produced, rather than using pre-established typologies, institutions, and language (CEFAï, 2013).

One example of this interaction occurred in early 2019, when more than one hundred children and adolescents, students of public schools or participants of the programs offered by the CSOs, participated in the municipal pre-conference on the rights of children and adolescents. During the event, they exposed their demands and desires to discuss how to mobilize and act to guarantee their rights. The observation of this event allowed us to perceive the differences and gaps in the speeches and wishes between the policy managers and the affected publics.

Table 3 below summarizes the stages of the research and its objectives, as well as the research strategies and the locus where these strategies were implemented. The box also presents the questions guiding each stage.

The methodological path presented here allowed to re-construct the narrative of this public arena, together with its actors. It highlights the processes of social inquiry produced in the last thirteen years. The game of scales and the crossing of different perspectives of analysis have made it possible to identify (1) the main events and mechanisms of the public arena in this 
period, reconstituting the scenario for the problematic situations; (2) the main spokespersons and publics mobilized from this arena, their roles and forms of engagement (as well as those who are absent); (3) the successive confrontations of problematic situations, ${ }^{5}$ over time, and how they are overcome, highlighting the processes - and its obstacles - of learning co-creation, dissemination, and sharing (processes of social inquiry); and (4) the effects and developments of these arguments and actions, regarding their capacity to criticize, problematize, deliberate, denounce, and make judgments, which have consequences both in response to public problems and in the public policy.

\section{Box 3}

\section{Analytical focus and methodological path to conduct the ethnography of the public arenas}

\begin{tabular}{|c|c|c|c|}
\hline Stage & Focus & Research strategy & Locus of the study \\
\hline $\begin{array}{c}\text { 1- Mapping and analyzing } \\
\text { the configuration of the } \\
\text { public arena' s network }\end{array}$ & $\begin{array}{c}\text { Understanding the outlines of the } \\
\text { public arena, the main actors and } \\
\text { interactions (structural analysis) }\end{array}$ & Mapping, cartography & $\begin{array}{c}\text { Social innovation } \\
\text { ecosystem, networks that } \\
\text { form the public arena }\end{array}$ \\
\hline \multicolumn{2}{|c|}{$\begin{array}{c}\text { Guiding questions: Who are the support actors? What are their roles? Which initiatives aim to respond to the } \\
\text { city's public problem? What are the problematic situations that they aim to address? What are the } \\
\text { interactions established? Whom are the people affected? What are the proposed solutions? What are }\end{array}$} \\
the methodologies and technologies presented? What is the incidence in public arenas?
\end{tabular}

Guiding questions: Who are the spokespersons? What are the events? What are the themes discussed? What problematic situations have people lived? How are these situations faced? What are the consequences? What is the narrative when facing the problem? What are the arguments? What are the controversies?

\begin{tabular}{|c|c|c|c|}
\hline Stage & Focus & Research strategy & Locus of the study \\
\hline $\begin{array}{c}\text { 3- Identifying and } \\
\text { monitoring scenes of } \\
\text { reciprocal adjustment }\end{array}$ & $\begin{array}{c}\text { Identifying the spaces of building } \\
\text { commitment and where conflicts } \\
\text { among different publics engaged in } \\
\text { the public arena emerge }\end{array}$ & $\begin{array}{c}\text { Direct, continued, and } \\
\text { systematic observation }\end{array}$ & $\begin{array}{c}\text { Spaces of connection } \\
\text { and dialogue, such as } \\
\text { the forums or councils of } \\
\text { public policies }\end{array}$ \\
\hline
\end{tabular}

Guiding questions: How are the actors organized to request their demands? What are the legal and institutional mechanisms, objects, and rules that the public used to protect the rights of children and adolescents?

How can representation and legitimacy be built in the public arena? What is the scale of publicity used in the arena? Who are the protagonists, the spectators, the narrators, and the audience? Who is responsible?

\begin{tabular}{|c|c|c|c|}
\hline Stage & Focus & Research strategy & Locus of the study \\
\hline $\begin{array}{c}\text { 4- Follow-up with affected } \\
\text { people and their life } \\
\text { experience }\end{array}$ & $\begin{array}{c}\text { How does the action occur } \\
\text { (if it does), and what are the } \\
\text { consequences? Recovery time } \\
\text { sequences while they are produced }\end{array}$ & $\begin{array}{c}\text { Direct and systematic } \\
\text { observation }\end{array}$ & $\begin{array}{c}\text { Government agencies and } \\
\text { civil society organizations } \\
\text { that work with children } \\
\text { and adolescents }\end{array}$ \\
\hline
\end{tabular}

Guiding questions: How do affected people understand the public problem? Do they mobilize and act around this problem? How? How does the attribution of responsibility, the elaboration of a complaint, the unfolding of a violation of right occur? What are the consequences for the affected people? Do they publicize their problems? How?

Source: Elaborated by the authors.

The analysis conducted in this study made it possible to highlight the advances and limits of the dynamics of collective learning in this network, the extent to which they generate "democratic experimentation," and what this means to public action. In this sense, at the end of the broader research, it will be possible to understand the extent to which the dynamics identified in the public arena of children and adolescents' rights protection are closer or not to the notion of social innovation living laboratories, and what elements influence this relation.

\footnotetext{
${ }^{5} \mathrm{An}$ example of problematic situation observed during the research was the implementation at the municipal level of the new law on the relationship between the government and civil society organizations in the collaborative governance of public policies - The event generated a series of debates, clashes, and developments resulting in the Municipal Decree 17361 of 2017.
} 
As Terzi (2015) points out, every social phenomenon, including political action, has a narrative component in its constitution. This effort to recover this component is important not only for researchers but especially for the actors who engage in the public arena, as it makes it possible to understand better how democratic learning is produced and its effects on public action and to public policies.

\section{FINAL CONSIDERATIONS}

This article presented a theoretical approach and a methodological path to understand the phenomenon of social innovation living laboratories (SILLS) formed in the public arenas of cities. The study was developed based on pragmatist studies in the field of sociology of public problems and public action, using key conceptual categories to understand the processes of learning, co-construction, and dissemination of knowledge in social innovation ecosystems (SIE), as well as putting into practice, strengthening, and/or rethinking the experiences of SILLs.

Based on these conceptual categories and adopting the "ethnography of public arenas" (CEFAï, 2009, 2012) the proposed methodological path included four stages that focused on different scales and used different research strategies: (1) Mapping and analyzing the configuration of the public arena network; (2) Reconstitution and analysis of the public arena's trajectory; (3) Identifying and monitoring scenes of reciprocal adjustment; and (4) Follow-up with affected people and their life experience. The study conducted, therefore, a "political ethnography" or an "anthropology of citizenship" (CEFAï, 2007), revealing how the city's living laboratories emerge and co-produce social innovations, i.e., promote real consequences in public arenas, public action, and in public policies.

The application of this analytical-methodological approach has also allowed us to identify, investigate, and support a SILL experience in the public arena of children and adolescents' rights protection from a new perspective. The practical experience connecting actions of teaching, research, and university extension, contributed to understanding that these phenomena are embedded in the territory and are built over time, from collective actions. They are implemented by various actors, mechanisms, and resources engaged in addressing the public problem. This constitutes a collective and collaborative process of knowledge construction, involving a plurality of actors (government, university, social entrepreneurs, CSOs, and the population that is directly affected).

This study demonstrates that the processes of co-construction of knowledge can result from processes of experimentation around public problems, which Dewey (1927) conceptualized as "social inquiry." Such processes occur in laboratories of democratic experimentation; they have a history and a geographic location. They are events occurring in different scales - from institutional to daily politics - where people who suffer and act on the consequences of the public problems (communities of practice) have the objective possibility of producing knowledge and collective intelligence to address the challenges they faced.

The research in the public arena studied demonstrated that the complex public problems faced in modern democracies require new mechanisms, strategies, and practices of public action. In this scenario, experts, universities, and research and training centers are involved in these dynamics, not as protagonists - as observed most of the time in SILLs experiences -, but as part of this network, promoting connections to produce knowledge and build responses to the new challenges.

The approach proposed and applied in this article suggests that SILLs can be studied as phenomena that contribute to strengthen the political dimension of social innovation processes in cities. Based on this perspective, the study of SILLs can help visualize, monitor, and analyze the concrete civic practices, and comprehend whether such practices make changes in the territorial paths.

\section{ACKNOWLEDGMENTS}

The authors thank Foundation for Research and Innovation Support of the State of Santa Catarina (FAPESC), the National Council for Scientific and Technological Development (CNPq), and the Santa Catarina State University (UDESC) for the financial support of this research. 


\section{REFERENCES}

ANDION, C.; ALPERSTEDT, G. D.; GRAEFF, J. F. Ecossistema de inovação social, sustentabilidade e experimentação democrática: um estudo em Florianópolis. Revista de Administração Pública, v. 54, n. 1 p. 181-200, 2020.

ANDION, C.; ALPERSTEDT, G. D.; GRAEFF, J. F. Social Innovation Ecosystems and Cities: Co-Construction of a Collaborative Platform. In: HOWALDT, J. et al. (Eds.) Atlas of Social Innovation. (2nd Volume: A World of New Practices). Dormunt: TU Dormunt University, European School of Social Innovation, 2019.

ANDION, C. et al. Civil society and social innovation in the public sphere: a pragmatic perspective. Revista de Administração Pública, v. 10, n. 3, p. 40-58, 2017.

ANDION, C; MORAES, R. L; GONSALVES, A.K.R. Civil society organizations and social innovation. How and to what extent are they influencing social and political change? CIRIEC - España. Revista de Economia Publica, Social y Cooperativa. n. 90, p. 5-34, 2017.

ANSELL, C. Pragmatist Democracy: Evolutionary Learning as Public Philosophy. Oxford: Oxford Scholarship Online, 2011.

ANSELL, C. What is democratic experiment? Contemporary Pragmatism, v. 9, n. 2, p. 159-180, 2012.

BACCARNE, B. et. al. Governing quintuple helix innovation: urban living labs and socio-ecological entrepreneurship. Technology Innovation Management Review, v. 6, n. 3, p. 22-30, 2016.

BIGNETTI, L. P. As inovações sociais: uma incursão por ideias, tendências e focos de pesquisa. Ciências Sociais Unisinos, v. 47, n. 1, p. 3-14, 2011.

BOHMAN, J. Realizing deliberative democracy as a model of inquiry: pragmatism, social facts and normative theory. Journal of Speculative Philosophy, v. 18, n. 1, p. 3-43, 2004.

BOLTANSKI, L.; THÉVENOT, L. On justification: economies of worth. Princeton: Princeton University Press, 2006.

BRIGGS, X. Democracy as problem solving civic capacity in communities across the globe. Cambridge: MIT Press, 2008.

CEFAII, D. Qu'est-ce qu'une arène publique? Quelques pistes pour une approche pragmatist. In: CEFAÏ; D.; JOSEPH, I. (Org.). L'héritage du pragmatisme. Conflits d'urbanité et épreuves de civisme. La Tour d'Aigues: Éditions de l'Aube, 2002. p. 51-82.

CEFAÏ, D. Pourquoi se mobilise-t-on? Les théories de l'action collective. Paris: La Découverte, 2007.

CEFAÏ, D. Como nos mobilizamos? A contribuição de uma abordagem pragmatista para a sociologia da ação coletiva. Dilemas, v. 2, n. 4, p. 11-48, 2009.

CEFAÏ D. Qu'est-ce qu'une arène publique? Quelques pistes pour une approche pragmatiste. In: CEFAÏ, D.; JOSEPH, I. (Eds.). L’héritage du pragmatisme. Conflits d'urbanité et épreuves de civisme. La Tour d'Aigues: Éditions de l'Aube, 2012.

CEFAÏ, D. Investigar los problemas públicos: con y más allá de Joseph Gusfield. Prefácio. In: GUSFIELD, J. R. La cultura de los problemas públicos los conductores alcoholizados y el orden simbólico. Buenos Aires: Siglo XXI Editores, 2014.
CEFAÏ, D. Públicos, problemas públicos, arenas públicas. Novos Estudos CEBRAP, v. 36, n. 1, p. 187-213, 2017.

CEFAÏ, D.; TERZI, C. L'expérience des problèmes publics. Paris: Perspectives Pragmatistes, 2012.

CHATEAURAYNAUD, F. Argumenter dans un champ de forces: essai de balistique sociologique. Paris: Petra, 2011.

CHATEAURAYNAUD, F. A captura como experiência. Investigações pragmáticas e teorias do poder. Revista Brasileira de Ciências Sociais, v. 32, n. 95: e329504, p. 1-20, 2017.

CHATEAURAYNAUD, F.; DEBAZ, J. Au bord de l'irréversible: sociologie pragmatique des transformations. Paris: Petra, 2017.

COMETTI, J.-P. Qu'est-ce que le pragmatisme ? Paris: Folio essais, 2010.

DAVI, L. B. D. Organizações da sociedade civil e inovação social na esfera pública: a experiência do Instituto Padre Vilson Groh. Master Thesis (Master Degree on Administration) - Universidade Estadual de Santa Catarina, Florianópolis, 2014.

DEWEY, J. The public and its problems. Chicago: Swallow Press, 1927.

DEWEY, J. Logic: the theory of inquiry. New York: Henry Holt and Company, 1956.

FREGA, R. Le pragmatism comme philosophie sociale et politique. Paris: Le Bord de l'Éau, 2015.

FREGA, R. Pragmatism and the wide view of democracy. Gewerbestrasse: Palgrave Macmillan, 2019.

FUNG, A.; WRIGHT, E. O. Deepening democracy: institutional innovations in empowered participatory governance. London: Verso, 2003.

GONSALVES, A. K. R. Sistema de garantia de direitos da criança e do adolescente como ação pública. Master Thesis (Master Degree on Administration) - Universidade Estadual de Santa Catarina, Florianópolis, 2015.

GONSALVES, A.; ANDION, C. Ação Pública e inovação social: uma análise do Sistema de Garantia de Direitos da Criança e do Adolescente de Florianópolis. Revista O\&S, vol.26, n.89, p. 221 - 248, 2019.

GASCÓ, M. Living labs: implementing open innovation in the public sector. Government Information Quarterly, v. 34, n. 1, p. 90-98, 2017.

HERSELMAN, M.; CALLAGHAN, R. Applying a living lab methodology to support innovation in education at a university in South Africa. The Journal for Transdisciplinary Research in Southern Africa, $v$. 11, n. 1, p. 21-28, 2015.

HODSON, M.; GEELS, F. W.; MCMEEKIN, A. Reconfiguring urban sustainability transitions, analyzing multiplicity. Sustainability, v. 9, n. 2, 2017.

HOWALDT, J.; DOMANSKI, D.; KALETKA, C. Social innovation: towards a new innovation paradigm. Revista de Administração Mackenzie, v. 17, n. 6, p. 20-44, 2016.

HOWALDT, J.; KOPP, R. Shaping social innovation by social research. In: FRANZ, H. W.; HOCHGERNER, J.; HOWALDT, J. Challenge social 
innovation: potentials for business, social entrepreneurship, welfare and civil society. New York: Springer, 2012.

HOWALDT, J. et al. Atlas of social innovation: new practices for a better future. Dortmund: TU Dortmund University, 2018.

INSTITUTO COMUNITÁRIO GRANDE FLORIANÓPOLIS - ICOM. Sinais vitais: crianças e adolescentes em Florianópolis. Florianópolis: ICOM, 2010.

INSTITUTO COMUNITÁRIO GRANDE FLORIANÓPOLIS - ICOM. Sinais vitais: crianças e adolescentes em Florianópolis. Florianópolis: ICOM, 2016

JANIN, C.; PECQUEUR, B. Les living labs: remise en question des processus de mise en marché et de politique publique. Canadian Journal of Regional Science, v. 40, n. 1, p. 5-11, 2016.

LASCOUMES, P.; LE GALÈS, P. Sociologia da ação pública. Maceió: Edufal, 2007.

LATOUR, B. Reagregando o social: uma introdução à teoria atorrede. Salvador: EDUFBA, 2012.

LEMINEN, S.; WESTERLUND, M. Living labs as open innovation networks. Technology Innovation Management Review, v. 2, n. 9, p. 6-11, 2016

LÉVESQUE, B. Économie sociale et solidaire et entrepreneur social: vers quels nouveaux écosystèmes. Reveue Interventions économiques, n. 54, 2016.

MASI, S. Social labs: identifying Latin American living labs. Humanities and Social Sciences, v. 4, n. 3, 2016.

MOULAERT, F.; MACCALLUM, D.; HILLIER, J. Social innovation: intuition, percept, concept, theory and practice. In: MOULAERT, F. et al. (Eds.). The international handbook on social innovation: collective action, social learning and transdisciplinary. Cheltenham, UK; Northampton, Massachusetts: Edward Elgar Publishing, 2013.

MULVENNA, M. et al. Living labs as engagement models for innovation. In: CUNNINGHAM, P.; CUNNINGHAM, M. (Eds.). Proceedings eChallenges-2010. Poland: International Information Management Corporation, 2010. p. 1-11.

NEUMEIER, S. Why do social innovations in rural development matter and should they be considered more seriously in rural development research? Proposal for a stronger focus on social innovations in rural development research. Sociologia Ruralis, v. 52, n. 1, p. 48-69, 2012.

NORTH, P.; LONGHURST, N. Grassroots localisation? The scalar potential of and limits of the 'transition' approach to climate change and resource constraint. Urban Studies, v. 50, n. 7, p. 1423-1438, 2013.

NYSTRÖN, A. et al. Actor roles and role patterns influencing innovation in living labs. Industrial Marketing Management, v. 43. n. 3, p. 483495, 2013.

PELKA, B.; TERSTRIEP, J. Mapping social innovation maps. The state of research practice across Europe. European Public \& Social Innovation Review, v. 1, n. 1, p. 3-16, 2016.
PINTO, M.; FONSECA, P. Profundizando la comprensión de los living labs de Brasil. Revista CTS, v. 23, n. 8, p. 231-247, 2013.

QUÉRÉ, L. Action située et perception du sens In: FORNEL, M. de; QUÉRÉ, L. (Orgs.). La logique des situations. Paris: Éditions de l'EHESS, 1999. p. 301-338.

QUÉRÉ, L.; TERZI, C. Pour une sociologie pragmatiste de l'experience publique. Quelques apports mutuels de la philosophie pragmatiste et de l'ethnométhodologie. SociologieS, 2015. Available at: <https:// journals.openedition.org/sociologies/4949>. Accessed on: Aug. 23, 2018.

RAMÓN, H. D. et al. Living labs en la región noroeste de la provincia de Buenos Aires. In: WORKSHOP DE INVESTIGADORES EN CIENCIAS DE LA COMPUTACIÓN, 18., 2016, Entre Ríos, Argentina. Anales... Entre Ríos, Argentina: WICC, 2016.

REVEL, J. Jogos de escala: a experiência da microanálise. São Paulo: Editora da FGV, 1996.

REDE DE MONITORAMENTO CIDADÃO DE FLORIANÓPOLIS RMC. Relatório Anual de Progresso dos Indicadores (RAPI) 2019. Florianópolis: Rede Ver a Cidade de Florianópolis, dez. 2019. Available at: <https://materiais.floripamanha.org/relatorio-indicadoresflorianopolis-2019>. Accessed on: Aug. 23, 2018.

ROUX, E.; MARRON, Q. Les livings labs, de nouveaux dispositifs d'action publique pour penser les métropoles et les territoires. Canadian Journal of Regional Science, v. 40, n. 1, p. 33-41, 2016.

SCHIAVO, E.; SANTOS-NOGUEIRA dos C.; VERA, P. Entre la divulgación de la cultura digital y el surgimiento de los laboratorios ciudadanos. El caso argentino en el contexto latinoamericano. Revista Iberoamericana de Ciencia, Tecnología y Sociedad, v. 23, n. 8, p. 79-89, 2013.

SCHUURMAN, D. Living labs: concepts, tools, and cases. Info, v. 17, n. 4, p. 45-59, 2015.

SHIELDS, P. Rediscovering the taproot: is classical pragmatism the route to renew public administration? Public Administration Review v. 68, n. 2, p. 205-221, 2008.

TERZI, C. La composante narrative du monde pratique Intervention. In : CONGRES DE L'AFSP, 13., 2015, Aix-en-Provence. Annales... Aix-en-Provence : AFSP, 2015.

WOLFRAM, M.; FRANTZESKAKI, N. Cities and systemic change for sustainability: prevailing epistemologies and an emerging research agenda. Sustainability, v. 8, n. 2, p. 1-18, 2016.

YAÑEZ-FIGUEROA, J. A.; RAMIREZ-MONTOYA, M. S.; GARCIAPEÑALVO F. J. Systematic mapping of the literature: social innovation laboratories for the collaborative construction of knowledge from the perspective of open innovation. In: INTERNATIONAL CONFERENCE ON TECHNOLOGICAL ECOSYSTEMS FOR ENHANCING MULTICULTURALITY, 4., 2016, Salamanca. Proceedings... Salamanca: ACM, 2016.

ZASK, J. L'enquête sociale comme inter-objectivation. La croyance et l'enquête. Aux sources du pragmatisme. Raisons pratiques, v. 15, n. 1, p. 141-165, 2004. 
Master in Administration from the Federal University of Santa Catarina (UFSC); Ph.D. student of the Graduate Program in Administration at the Santa Catarina State University (UDESC), Florianópolis - SC, Brazil. E-mail: magalhaesgthiago@gmail.com

\section{Carolina Andion}

\section{ORCID: https://orcid.org/0000-0003-4723-3437}

Post-Doctoral in Social Economy from Valencia University; Ph.D. in Human Science from the Federal University of Santa Catarina (UFSC); Professor of the Public Administration Department and Administration Graduate Program of the Santa Catarina State University (UDESC), Florianópolis - SC, Brazil.

E-mail: andion.esag@gmail.com

Graziela Dias Alperstedt

\section{ORCID: https://orcid.org/0000-0003-0144-0406}

Post-Doctoral in Administration from Fundação Getúlio Vargas (EAESP/FGV); Ph.D. in Production Engineering and Systems from the Federal University of Santa Catarina (UFSC); Professor of the Business Administration Department and Administration Graduate Program of the Santa Catarina State University (UDESC), Florianópolis - SC, Brazil. E-mail: gradial@gmail.com 